\title{
HUBUNGAN ANTARA DUKUNGAN KELUARGA DENGAN KEINGINAN UNTUK SEMBUH PADA PENYALAHGUNA NAPZA DI LEMBAGA PEMASYARAKATAN WIROGUNAN KOTA YOGYAKARTA
}

\author{
Yulia Isnaini, Widodo Hariyono, Isti Ken Utami \\ Fakultas Kesehatan Masyarakat, Universitas Ahmad Dahlan, Yogyakarta
}

\begin{abstract}
Background: Drugs abuse case like the iceberg phenomenon to appear above the sea surface, while underneath the biggest does not appear. Mortality or the number of the case continue to increase in geometrical progression and risk of disease spread hepatitis B / C of $80 \%$ and HIV / AIDS as much as $40-50 \%$ and the number was about the abuse of all sections of the community. So that the efforts that seriously not only in prevention but the recovery of those who have become a votary affected which includes the restoration of the medical and social. Family support is considered able to weaken the impact of stress and can directly strengthen the individual's mental health. Goal of this research is to find out the relationship between family support with the desire to recover the drugs abuse Wirogunan correctional facility in Yogyakarta.

Method: This was analytical observations cross sectional design. The respondent was 50 people related to criminal cases drugs abuse. Samples taken with the technique Totality Sampling with the criteria set inklusi and eksklusi. Analysis of the data used was the Chi Square test statistics.

Results: There was relationship between the support the family with the desire to recover in drugs abuse in the correctional facility Wirogunan Yogyakarta to see the value of Asymp. Sig < á $(0.002<0.05)$ and the calculated Chi Square 12.605> Chi Square table (df $=2 \rightarrow 5.991)$. Hypothetical possibility or the probability is zero $(\mathrm{Ho})$ is small, so Ho rejected the hypothetical alternative $(\mathrm{Ha})$ accepted.

Conclusion: There was relationship between the support family with the desire to recover in drugs abuse in the correctional facility Wirogunan Yogyakarta with the support of the family contributed to 44.9 percent against the desire to recover.
\end{abstract}

Keywords: Family support, desire to recover, drugs abuse.

\section{PENDAHULUAN}

Dewasa ini, penyalahgunaan ketergantungan Narkoba di Indonesia telah sampai pada titik yang mengkhawatirkan. Berdasarkan data yang dihimpun Badan Narkotika Nasional, jumlah kasus narkoba per tahunnya terus mengalami peningkatan. Tingginya angka penyalahgunaan narkoba kemungkinan disebabkan karena produksi Narkoba yang terus meningkat sehingga mudah didapat, jaringan komunikasi yang semakin canggih dan faktor sosial ekonomi. Alasan berikutnya adalah karena lintas gender, lintas usia dan lintas lapisan, artinya pengguna narkoba sudah makin meluas, meliputi laki-laki dan wanita, tua muda, hingga berbagai kelas ekonomi di masyarakat yang menuntut upaya sungguh-sungguh tidak hanya dalam pencegahan tetapi memulihkan mereka yang sudah terlanjur menjadi pecandu napza. Pemulihan pecandu napza sendiri mencakup pemulihan secara medis (rehabilitasi medis) dan secara sosial (rehabilitasi sosial).

Angka kematian atau jumlah kasus yang terus meningkat dalam deret ukur. Kasusnya seperti gunung es yang mencuat di atas permukaan laut, sedangkan bagian terbesar dibawahnya tidak tampak. World Health Organization (WHO) menyatakan bahwa jika terdata satu kasus berarti yang terjadi ada sepuluh kasus dan tingginya angka kematian per hari karena penyalahgunaan narkoba yaitu 2-3 orang per harinya. Hal ini belum menggambarkan data yang sebenarnya karena 
sering penyebab kematian yang sebenarnya tidak diungkap oleh keluarga karena rasa malu. Banyak kasus narkoba dilaporkan meninggal karena sebab lain (perdarahan otak, jantung, dan kecelakaan). Serta bahaya penyakit menular hepatitis $\mathrm{B} / \mathrm{C}$ dan HIVIAIDS, laporan menunjukkan $80 \%$ pengguna narkoba dengan jarum suntik menderita hepatitis B/C dan $40-50 \%$ tertular HIV. Penyebabnya adalah pemakaian jarum suntik yang tidak steril dan bergantian.

Sebagian orangtua, mempunyai anak yang terlibat napza seringkali menjadi suatu aib keluarga. Tidak jarang orangtua langsung meninggalkan anaknya begitu saja, atau terlena oleh rasa gagal menjadi orangtua sehingga melupakan problem yang utama. Banyak orangtua merasa telah melakukan sesuatu, setelah memasukkan anaknya ke panti rehabilitasi dan merasa upaya itu sudah cukup. Memasukkan anak ke panti rehabilitasi memang merupakan salah satu jalan yang saat ini masih dianggap yang paling tepat. Namun, tingkat relaps (kembali menjadi penderita ketergantungan obat) tinggi yaitu 60-70\%. Lingkungan yang mendukung terutama keluarga sangat berperan dalam proses penyembuhan seseorang yang ketergantungan obat. Hal ini disebabkan, tidak banyak dari mereka yang keinginan sembuhnya datang dari dalam dirinya sendiri. Bila keluarga hanya menyuruh mereka untuk berhenti tetapi tidak mewujudkannya dalam dorongan positif, hasilnya tidak akan nyata. Sugesti yang dimunculkan dari obat-obatan itu akan lebih kuat daripada suruhan untuk berhenti dari orang lain. Lebih banyak pengguna membutuhkan dukungan orangtua daripada yang mempunyai tekad baja untuk lepas.

Berkembangnya asumsi di masyarakat pencandu narkoba sekeras apa pun berusaha tidak bisa sepenuhnya sembuh. Pencandu narkoba selalu identik dengan kekerasan, bertingkah seenaknya, mengganggu orang lain, dan merusak. Stigma negatif dan sebagai sampah masyarakat selalu ditujukan pada para pencandu narkoba. Stigma negatif itu yang akhirnya kembali membuat seorang mantan pencandu narkoba kembali terpuruk. Perasaan kesendirian, tak punya kawan, membuat mereka kembali terbenam dalam gelimang narkoba. Hanya sebagian kecil mantan pencandu yang berhasil menata kembali hidupnya walau harus melewati perjuangan yang keras dan berliku.

Berdasarkan fenomena di atas maka peneliti tertarik untuk melaksanakan penelitian untuk mengetahui hubungan antara dukungan keluarga dengan keinginan untuk sembuh pada pasien penyalahguna napza.

\section{METODE PENELITIAN}

Penelitian ini merupakan penelitian studi observasional dengan menggunakan rancangan penelitian cross sectional. Populasi dalam penelitian ini adalah seluruh narapidana di Lembaga Pemasyarakatan Wirogunan Yogyakarta yang terkait kasus penyalahgunaan Napza yaitu sebanyak 50 orang. Sampel dari penelitian ini adalah totality sampling yaitu seluruh populasi dijadikan sampel penelitian yaitu sebanyak 50 orang dengan kriteria inklusi yang harus dipenuhi sampel penelitian ini yaitu berstatus sebagai narapidana di Lembaga Pemasyarakatan Wirogunan yang masih memiliki keluarga. Alat dalam penelitian ini adalah kuesioner. Kuesioner digunakan untuk memperoleh informasi dari variabel-variabel yang diteliti.

Pengolahan data dilakukan dengan bantuan komputer dengan program SPSS. Analisis data meliputi analisis univariat dan bivariat. Adapun langkah-langkah dalam analisis penelitian ini adalah:

a. Analisis univariat yaitu secara deskriptif dengan menggunakan tabel distribusi frekuensi 
b. Analisis bivariat yaitu secara analitik untuk mengetahui hubungan antara dua variable dengan uji chi-square dan melihat besarnya sumbangan dari Contingency Coefficient (CC).

\section{HASIL PENELITIAN DAN PEMBAHASAN}

\section{a. Hasil Penelitian}

1) Karakteristik Responden

a) Distribusi Frekuensi Responden Menurut Umur

Umur dalam penelitian ini dibedakan menjadi tiga kategori, yaitu umur $\leq 20$ tahun, umur 21-30 tahun dan umur $\geq 31$ tahun. Distribusi frekuensi responden menurut umur dapat dideskripsikan sebagai berikut :

Tabel 3. Distribusi Frekuensi Responden Menurut Umur pada Penyalahguna Napza di Lapas Wirogunan Yogyakarta Tahun 2009

\begin{tabular}{lcc}
\hline Golongan Umur & Frekuensi & Persen (\%) \\
\hline$\leq 20$ tahun & 3 & 5 \\
\hline $21-30$ tahun & 32 & 64 \\
\hline$\geq 31$ tahun & 15 & 30 \\
\hline Jumlah & 50 & 100
\end{tabular}

Berdasarkan tabel 3, diketahui bahwa dari 50 responden yang diteliti, sebagian besar berada pada rentang umur 21-30 tahun dengan jumlah 32 orang (64\%) yang merupakan usia remaja akhir atau dewasa awal dan yang paling sedikit adalah umur $\leq 20$ tahun yang hanya berjumlah 3 orang.

b) Distribusi Frekuensi Responden Menurut Jenis Kelamin

Jenis kelamin dalam penelitian ini dibedakan menjadi dua kategori, yaitu laki-laki dan perempuan. Distribusi frekuensi responden menurut jenis kelamin dapat dideskripsikan sebagai berikut:

Tabel 4. Distribusi Frekuensi Responden Menurut Jenis Kelamin pada Penyalahguna Napza di Lapas Wirogunan Yogyakarta Tahun 2009

\begin{tabular}{ccc}
\hline \multicolumn{1}{c}{ Jenis Kelamin } & Frekuensi & Persen (\%) \\
\hline Laki-laki & 43 & 86 \\
\hline Perempuan & 7 & 14 \\
\hline Jumlah & 50 & 100 \\
\hline
\end{tabular}

Berdasarkan tabel 4, diketahui bahwa dari 50 responden yang diteliti, sebagian besar berjenis kelamin laki-laki yaitu sejumlah 43 $(86 \%)$ responden.

c) Distribusi Frekuensi Responden Menurut Tingkat Pendidikan

Tingkat pendidikan dalam penelitian ini dibedakan menjadi empat kategori, yaitu SD, SMP, SMA dan Perguruan Tinggi. Distibusi frekuensi responden menurut tingkat pendidikan dapat dideskripsikan sebagai berikut: 
Tabel 5. Distribusi Frekuensi Responden Menurut Tingkat Pendidikan pada Penyalahguna Napza di Lapas Wirogunan Yogyakarta Tahun 2009

\begin{tabular}{lcc}
\multicolumn{1}{c}{ Tingkat Pendidikan } & Frekuensi & Persen (\%) \\
\hline SD & 6 & 12 \\
\hline SMP & 8 & 15 \\
\hline SMA & 29 & 56 \\
\hline Perguruan Tinggi & 9 & 17 \\
\hline \multicolumn{1}{c}{ Jumlah } & 50 & 100 \\
\hline
\end{tabular}

Berdasarakan tabel 5, diketahui bahwa dari 50 responden yang diteliti, sebagian besar berpendidikan SMA yaitu sejumlah $29(56 \%)$ responden.

d) Distribusi Frekuensi Responden Menurut Daerah Asal

Daerah asal dalam penelitian ini dibedakan menjadi dua kategori, yaitu responden yang berasal dari daerah Yogyakarta dan responden yang berasal dari luar Yogyakarta dapat dideskripsikan sebagai berikut :

Tabel 6. Distribusi Frekuensi Responden Menurut Daerah Asal pada Penyalahguna Napza di Lapas Wirogunan Yogyakarta Tahun 2009

\begin{tabular}{|c|c|c|}
\hline Daerah Asal & Frekuensi & Persen (\%) \\
\hline Yogya & 36 & 72 \\
\hline Luar Yogya & 14 & 28 \\
\hline Jumlah & 50 & 100 \\
\hline
\end{tabular}

Berdasarkan tabel 6, diketahui bahwa dari 50 responden yang diteliti, sebagian besar berdomisili di daerah Yogyakarta yaitu sejumlah $36(72 \%)$ responden sehingga dapat disimpulkan bahwa sebagian besar responden selalu berinteraksi dengan keluarganya.

e) Distribusi Frekuensi Responden Menurut Lama Penggunaan Napza

Lama penggunaan Napza dalam penelitian ini dibedakan menjadi enam kategori, yaitu lama penggunaan $\leq 1$ tahun, 2-3 tahun, 4-5 tahun, 6-7 tahun, 8-9 tahun dan $\geq 10$ tahun dapat dideskripsikan sebagai berikut:

Tabel 7. Distribusi Frekuensi Responden Menurut Lama Penggunaan Napza pada penyalahguna Napza di Lapas Wirogunan Yogyakarta Tahun 2009

\begin{tabular}{lcc}
\hline Lama Penggunaan Napza & Frekuensi & Persen (\%) \\
\hline$\leq 1$ tahun & 19 & 38 \\
\hline $2-3$ tahun & 14 & 28 \\
\hline $4-5$ tahun & 8 & 16 \\
\hline 6-7 tahun & 2 & 4 \\
\hline 8-9 tahun & 4 & 8 \\
\hline$\geq 10$ tahun & 3 & 6 \\
\hline & 50 & 100 \\
\hline
\end{tabular}

Berdasarkan tabel 7 , diketahui bahwa dari 50 responden yang diteliti, 
sebagian besar lama penggunaannya $\leq 1$ tahun yaitu sejumlah 19 $(38 \%)$ responden.

\section{f) Distribusi Frekuensi Responden Menurut Jenis Napza yang \\ Digunakan}

Jenis Napza yang digunakan atau yang sering dipakai dalam penelitian ini dibedakan menjadi enam yaitu ganja, pil koplo, putaw, shabu-shabu, lexotan dan ekstasi. Distribusi frekuensi responden menurut jenis Napza yang disalahgunakan dapat dideskripsikan sebagai berikut :

Tabel 8. Distribusi Frekuensi Responden Menurut Jenis Napza yang Digunakan pada penyalahguna Napza di Lapas Wirogunan Yogyakarta Tahun 2009

\begin{tabular}{lcc}
\hline \multicolumn{1}{c}{ Jenis Napza yang Digunakan } & Frekuensi & Persen (\%) \\
\hline Ganja & 27 & 54 \\
\hline Pil Koplo & 6 & 12 \\
\hline Putaw & 5 & 10 \\
\hline Shabu-shabu & 5 & 10 \\
\hline Lexotan & 4 & 8 \\
\hline Ekstasi & 3 & 6 \\
\hline Jumlah & 50 & 100 \\
\hline
\end{tabular}

Berdasarkan tabel 8, diketahui bahwa dari 50 responden yang diteliti, sebagian besar menggunakan ganja yang termasuk jenis narkotika yaitu sejumlah $27(54 \%)$ responden.

\section{2) Analisis Univariat}

a) Distribusi Frekuensi Responden Menurut Dukungan Keluarga

Tabel 9. Analisis Univariat Dukungan Keluarga pada Penyalahguna Napza di Lembaga Pemasyarakatan Wirogunan Yogyakarta Tahun 2009

\begin{tabular}{ccc}
\hline Dukungan Keluarga & Frekuensi & Persen (\%) \\
\hline Tinggi & 27 & 54 \\
\hline Sedang & 14 & 28 \\
\hline Rendah & 9 & 18
\end{tabular}

Pada tabel 9, dari 50 responden yang diteliti terlihat bahwa sebagian besar responden mendapatkan dukungan keluarga yang tinggi sebesar 27 (54\%) responden.

b) Distribusi Frekuensi Responden Menurut Keinginan Untuk Sembuh

Tabel 10. Analisis Univariat Keinginan untuk sembuh pada Penyalahguna Napza di Lembaga Pemasyarakatan Wirogunan Yogyakarta Tahun 2009

\begin{tabular}{ccc}
\hline Keinginan untuk Sembuh & Frekuensi & Persen (\%) \\
\hline $\mathrm{Ya}$ & 33 & 66 \\
\hline Tidak & 17 & 34 \\
\hline
\end{tabular}


Berdasarkan tabel 10 , dari 50 responden yang diteliti terlihat bahwa sebagian besar responden memiliki keinginan untuk sembuh sebesar $33(66 \%)$ responden.

\section{3) Analisis Bivariat}

Analisis data yang digunakan dalam penelitian ini adalah chi square yaitu analisis yang bertujuan untuk mengetahui ada tidaknya hubungan antara dukungan keluarga dengan keinginan untuk sembuh. Berikut adalah hasil perhitungan yang telah dilakukan.

Tabel 11. Hubungan Antara Dukungan Keluarga dengan Keinginan Untuk Sembuh Pada Penyalahguna Napza di Lembaga Pemasyarakatan Wirogunan Yogyakarta Tahun 2009

\begin{tabular}{ccccc}
\hline & Value & df & $\begin{array}{c}\text { Asymp. Sig. } \\
(2-\text {-sided })\end{array}$ & $\begin{array}{c}\text { Contingency } \\
\text { Coefficient }\end{array}$ \\
\hline Pearson Chi Square & 12.605 & 2 & .002 & .449 \\
\hline
\end{tabular}

Berdasarkan tabel 11, dapat diketahui bahwa nilai Asymp. Sig < á $(0,002<0,05)$ jadi secara statistik bermakna hubungan antara dukungan keluarga dengan keinginan untuk sembuh pada penyalahguna Napza.

\section{b. Pembahasan}

Berdasarkan analisis univariat menunjukkan bahwa penyalahguna napza di Lembaga Pemasyarakatan Wirogunan Yogyakarta sebagian besar mendapatkan dukungan keluarga yang tinggi yaitu sebesar 27 (54\%) responden, $14(28 \%)$ responden mendapatkan dukungan keluarga yang sedang dan $9(18 \%)$ responden mendapatkan dukungan keluarga rendah.

Dukungan keluarga yang didapatkan oleh penyalahguna napza masih beragam, namun sebagian besar mendapatkan dukungan yang tinggi. Hal ini dikarenakan sebagian besar responden berasal dari daerah Yogyakarta sehingga responden dapat selalu berinteraksi dengan keluarganya. Permasalahan ini sesuai dengan pernyataan ${ }^{1}$, yaitu lingkungan yang mendukung terutama keluarga sangat berperan dalam proses penyembuhan seseorang yang ketergantungan obat. Hal ini disebabkan, tidak banyak dari mereka yang keinginan sembuhnya datang dari dalam dirinya sendiri, lebih banyak pengguna membutuhkan dukungan orang tua.

Beragamnya bentuk-bentuk dukungan keluarga yang meliputi dukungan emosional, penghargaan, instrumental, dan informatif menyumbang aksi sugesti yang positif terhadap permasalahan penyalahgunaan napza. Efek langsung dukungan terjadi sebagai hasil dari persepsi bahwa orang lain dalam jaringan sosialnya memberikan bantuan pada saat terjadi situasi yang penuh dengan stress, jadi efek ini tidak dipengaruhi oleh tingkat stress. Sebaliknya stress yang rendah, dukungan kurang mempengaruhi kesehatan tetapi pada saat terjadi stress berat, dukungan akan menjadi penyangga individu tersebut terhadap konsekuensi yang berbahaya ${ }^{2}$.

Berdasarkan analisis univariat menunjukkan bahwa penyalahguna napza di Lembaga Pemasyarakatan Wirogunan Yogyakarta sebagian besar memiliki keinginan untuk sembuh yaitu sebesar $33(66 \%)$ responden sedangkan sisanya 17 (34\%) responden tidak memiliki keinginan untuk sembuh. Keinginan untuk sembuh yang dimiliki oleh narapidana penyalahguna napza di Lembaga Pemasyarakatan Wirogunan Yogyakarta dikarenakan dukungan keluarga yang didapatkan relatif tinggi.

Mantan pecandu memiliki kecenderungan karakteristik tipikal yang berbeda dengan orang-orang pada umumnya, secara kognitif, behavioral, 
emosional, sosial dan interpersonal. Berkembangnya karakteristik ini disebabkan oleh efek Napza pada fungsi fisiologis maupun lamanya terpisah dari dunia nyata. Usaha pecandu untuk lepas dari belenggu napza merupakan perjuangan hidup yang dapat dikatakan seumur hidup, karena hampir seluruh dimensi pecandu telah rusak oleh kekacauan yang diakibatkan oleh kecanduannya. Para mantan penyalahguna harus waspada terhadap kemungkinan terjadinya relapse, yaitu kembali menggunakan Napza dengan pola yang sama. Salah satu usaha untuk memperkuat mantan penyalahguna untuk tetap hidup bersih dari Napza adalah dengan adanya family support ${ }^{3}$.

Dukungan keluarga mempengaruhi keinginan untuk sembuh. Hal ini serupa dengan pernyataan ${ }^{4}$ yang menyatakan bahwa sebenarnya para penyalahguna Napza ingin berhenti menggunakan napza karena Guilty Feeling. Guilty Feeling dapat memotivasi seorang pemakai napza untuk berhenti menggunakan Napza yang muncul dari dalam diri individu itu sendiri, dari luar individu, dan perasaan bertanggungjawab baik bertanggungjawab terhadap diri sendiri, keluarga, masyarakat, pemerintah maupun Tuhannya. Motivasi dari diri sendiri memberikan peluang 40 persen kesembuhan. Sisanya, dibutuhkan dukungan obat, keluarga, dan lingkungan. Penyembuhan seharusnya tidak hanya secara fisik, namun juga psikologis pecandu, seperti mengembalikan kepercayaan diri para pecandu.

Bila dilihat dari hasil analisis bivariat menggunakan chi square menunjukkan bahwa ada hubungan secara statistik antara dukungan keluarga dengan keinginan untuk sembuh pada penyalahguna napza di Lembaga Pemasyarakatan Wirogunan Yogyakarta dengan dukungan keluarga menyumbang 44,9 persen terhadap keinginan untuk sembuh yang dilihat dari contingency coefficient sedangkan 55,1 persen lagi untuk variabel lain dalam penelitian ini yang tidak diteliti.

Adanya hubungan antara variabel bebas dan variabel terikat tersebut maka penyalahguna napza sebagian besar telah menyadari kesalahannya dan ingin berhenti menggunakan napza karena Guilty Feeling serta adanya dukungan yang positif dari keluarga. Motivasi dari diri sendiri memberikan peluang 40 persen kesembuhan. Sisanya, dibutuhkan dukungan obat, keluarga, dan lingkungan. Hal ini perlu dipahami bahwa dukungan keluarga bukan sekedar memberikan bantuan tetapi yang penting adalah bagaimana persepsi si penerima terhadap makna dari dukungan tersebut. Adanya keeratan hubungan antara dukungan dengan ketepatan waktu pemberian dukungan, dukungan keluarga menjadi optimal pada situasi dan kondisi yang penuh dengan stress seperti pada penyalahguna napza ${ }^{3}$.

Hasil penelitian ini sesuai dengan hasil penelitian yang dilakukan ${ }^{5}$ terhadap penyalahguna napza di Panti Sosial Pamardi Putera "Sehat Mandiri" Yogyakarta yang mendapatkan hasil bahwa family support mengawal perjalanan hidup penyalahguna untuk kembali menjalani hidup sehat tanpa menggunakan napza lagi dan membantunya untuk bersosialisasi di masyarakat.

Hal tersebut juga dipertegas ${ }^{2}$ yang menyatakan bahwa individu yang merasa memperoleh dukungan secara emosional, penghargaan, instrumental dan informatif merasa lega karena diperhatikan, mendapat saran atau kesan yang menyenangkan pada dirinya. Demikian juga dukungan keluarga sebagai keberadaan, kejadian, kesediaan, kepedulian dari orang-orang yang dapat diandalkan, menghargai dan menyayangi. Hal serupa juga menyatakan bahwa secara spesifik dapat diterima bahwa 
orang yang hidup dalam lingkungan yang bersifat suportif, kondisinya jauh lebih baik daripada mereka yang tidak memilikinya. Dukungan mampu melemahkan dampak stress dan secara langsung memperkokoh kesehatan mental individu ${ }^{1}$.

\section{SIMPULAN DAN SARAN}

\section{a) Simpulan}

1) Narapidana penyalahguna napza di Lembaga Pemasyarakatan Wirogunan Yogyakarta sebagian besar mendapatkan dukungan keluarga dalam kategori tinggi yaitu sebesar 27 responden (54\%).

2) Narapidana penyalahguna napza di lembaga pemasyarakatan wirogunan Yogyakarta sebagian besar memiliki keinginan untuk sembuh yaitu sebesar 33 responden (66\%).

3) Ada hubungan antara dukungan keluarga dengan keinginan untuk senbuh pada penyalahguna napza di Lembaga Pemasyarakatan Wirogunan Yogyakarta.

\section{b. Saran}

1) Bagi Departemen Hukum dan Hak Asasi Manusia DIY

Hasil penelitian ini dapat dijadikan pertimbangan dalam pengambilan kebijakan oleh pihak terkait khususnya dalam penanggulangan narapidana terkait kasus Napza seperti adanya blok/sel dan penanganan khusus sehingga dapat dilakukan pembinaan psikologis meliputi pengembalian kepercayaan diri dan pengembangan skill yang intensif sebagai persiapan untuk kembali ke masyarakat.

2) Bagi Lembaga Pemasyarakatan Wirogunan Yogyakarta

Penelitian ini berupa pemahaman tentang kondisi psikologis narapidana terkait kasus Napza dapat bermanfaat sebagai sumbangan pemikiran kepada para pelaksana program pembinaan di lembaga Pemasyarakatan khususnya para pengambil keputusan dalam menentukan kebijakan perlakuan dan pembinaan terhadap narapidana misalnya adanya kegiatan rutin yang melibatkan keluarga sehingga keintiman hubungan orang tua dan anak dapat terjaga.

3) Bagi Penyalahguna Napza

Diharapkan penyalahguna napza dapat termotivasi dan berkeinginan untuk sembuh sehingga dapat menata hari esok yang lebih baik.

\section{DAFTAR PUSTAKA}

1. Cahya, N. I,. Guilty Feeling: Motivasi Berhenti pada Pemakai Napza, http:// etd.library.ums.ac.id, diakses tanggal 26 Maret 2009, Yogyakarta. 2006

2. Darojat, Z., Pendekatan Family Support Group dalam Pemulihan Korban Penyalahgunaan NAPZA di Panti Sosial Pamardi Putra "Sehat Mandiri" Yogyakarta, Skripsi, Fakultas Dakwah UIN, Yogyakarta. 2008

3. Kuntjoro, Z. S., Dukungan Sosial Pada lansia, Raja Grasindo Persada, Jakarta. 2002

4. Purwanti, A., Hubungan Antara Dukungan Sosial dengan Depresi pada Remaja Penyalahguna NAPZA, Jurnal IImu Keperawatan Vol. 01/No.01, Hal 1-4. 2006

5. Friedman, M. M., Keperawatan Keluarga Teori dan Praktik, EGC, Jakarta. 1992 